\title{
Weather Radar Data and Distributed Hydrological Modelling: An Application for Mexico Valley
}

\author{
Baldemar Méndez-Antonio ${ }^{1}$, Ernesto Caetano ${ }^{2}$, Gabriel Soto-Cortés ${ }^{3}$, Fabián G. Rivera-Trejo ${ }^{4}$, \\ Ricardo A. Carvajal Rodríguez ${ }^{1}$, Christopher Watts ${ }^{1}$ \\ ${ }^{1}$ Sonora University, Hermosillo, Mexico; ${ }^{2}$ National Autonomous University of Mexico, Mexico City, Mexico; ${ }^{3}$ Metropolitan Auto- \\ nomous University, Mexico City, Mexico; ${ }^{4}$ Tabasco Autonomous Juárez University, Villahermosa, Mexico. \\ Email: caetano@unam.mx
}

Received January $28^{\text {th }}, 2013$; revised March $2^{\text {nd }}, 2013$; accepted March $13^{\text {th }}, 2013$

Copyright (C) 2013 Baldemar Méndez-Antonio et al. This is an open access article distributed under the Creative Commons Attribution License, which permits unrestricted use, distribution, and reproduction in any medium, provided the original work is properly cited.

\begin{abstract}
The frequent occurrence of exceptionally very heavy rainfall in Mexico during the summer causes flash floods in many areas and major economic losses. As a consequence, a significant part of the annual government budget is diverted to the reconstruction of the disasters caused by floods every year, resulting hold up in the country development. A key element to mitigate the flash flood hazards is the implementation of an early warning system with the ability to process the necessary information in the shortest possible time, in order to increase structural and non-structural resilience in flood prone regions. The real-time estimation of rainfall is essential for the implementation of such systems and the use of remote sensing instruments that feed the operational rainfall-runoff hydrological models is becoming of increasing importance worldwide. However, in some countries such as Mexico, the application of such technology for operational purposes is still in its infancy. Here the implementation of an operational hydrological model is described for the Mixcoac river basin as part of the non-structural measures that can be applied for intense precipitation events. The main goal is to examine the feasibility of the use of remote sensing instruments and establish a methodology to predict the runoff in real time in urban river basins with complex topography, to increase the resilience of the areas affected by annual floods. The study takes data from weather radar operated by the National Meteorological Service of Mexico, as input to a distributed hydrological model. The distributed unit hydrograph model methodology is used in order to assess its feasibility in urban experimental basin. The basic concepts underlying the model, as well as calibration and validation are discussed. The results demonstrate the feasibility of using weather radar data for modeling rainfall-runoff process with distributed parameter models for urban watersheds. A product resulting from this study was the development of software Runoff Forecast Model (ASM), for application in distributed hydrological models with rainfall data in real time in watersheds with complex terrain, which are usually found in Mexico.
\end{abstract}

Keywords: Radar; Distributed Hydrologic Modeling; Resilience

\section{Introduction}

Soussan and Bourton [1] defined adaptation as the ability to respond and adapt to real or potential impacts under changing weather conditions in order to moderate damage. In the face of extreme hydrometeorological conditions the greater or lesser resilience or strength, defines vulnerability which a community is exposed. Lack of resilience is manifested at the structural, physical, economic, social, political, and institutional level. Thus, the human vulnerability and lack of resilience explain many of the large-scale disasters and y to decrease the risk of disaster, measures should be taken to modify those fac- tors [2]. In order to build resilience in areas vulnerable to flooding, structural and nonstructural measures must be taken. Early warning systems (EWS) supported by operational hydrological runoff prediction models are a fundamental part of the non-structural measures. The disaster risk reduction and increased preparedness to natural hazards in different development sectors have multiplier effects and accelerate the achievement of the Millennium Development Goals [3].

The use of distributed hydrological models has increased in the last three decades [4,5]. These models are developed in order to physically represent the hydrologi- 
cal processes occurring in a watershed through analogies and mathematical simplifications. Early attempts to develop distributed models were limited by computing capacity required for processing and storage of information, but the digital revolution, responsible for the huge growth in the quantity of geospatial data available today, has allowed the development of more robust distributed hydrological models [6]. It is noteworthy that the spatial and temporal variability of precipitation has a strong impact on the outcome of distributed hydrological modeling, while the density of the rain gauge network also plays an important role [7-9].

Additionally, EWS have been greatly improved with the development of geographic information systems (GIS) and the Internet [10]. Remote sensing instruments, such as radar and weather satellites, due to their ability to estimate the spatial variability of precipitation in real-time, are ideal for use in distributed hydrological modeling. The combination of remote sensing, GIS and the Internet, allows the collection and transmission of real-time data more efficiently. The data generated by these systems can be used as input to operational hydrological models and so estimate the basin response in the presence of extreme precipitation events. In Mexico, although efforts have been made to use this technology by both federal local governments and academic institutions, the results are still only at the diagnosis level [11].

This paper examines the use of weather radar data for operational hydrological modeling in an experimental catchment located in the metropolitan area of Mexico City. The methodology proposed here could easily be applied to others basins anywhere that radar data is available. Additionally, EWS can be integrated into contingency plans allowing countries to build resilience and prevent large losses from annual flooding, thus improving regional and national development.

\section{Study Area}

The selected case study area is the Mixcoac River experimental basin, located in Mexico City, (Figure 1). This

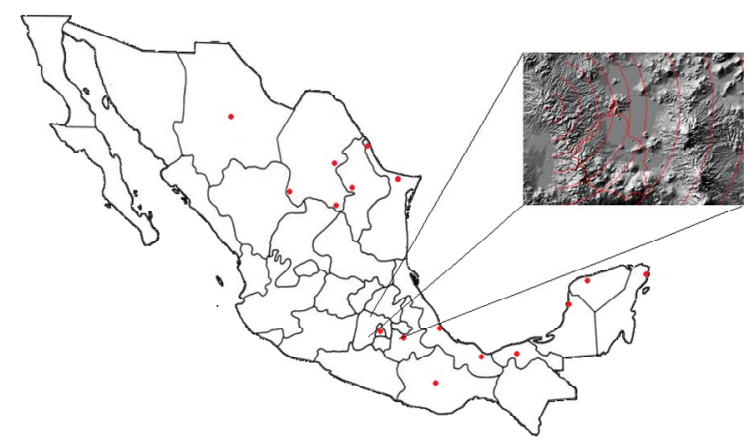

Figure 1. Basin study location and Mixcoac River Basin topography. is a mountain river, with low runoff in dry period and sudden and intense floods in the rainy periods. Intense precipitation occurs often due to topographically enhanced convection over this area [12]. This basin was selected for this study because of the availability of input data from: 1) the Cerro Catedral weather radar, located $35 \mathrm{~km}$ from the study basin (Figure 1); 2) runoff and precipitation estimates from 78 rain gauges network within the radar coverage area. This data set allows us to establish a robust relationship between rainfall and runoff that eventually will help calibrate the hydrological model.

\section{Hydrological Modeling}

In traditional hydrological models, the runoff is produced by the fraction of precipitation not absorbed by the soil, this flow component is referred as direct or surface runoff, and the volume portion of precipitation which has produced it, is called excess or effective precipitation [13]. This type of runoff is known as Horton excess infiltration mechanism and usually occurs in rivers with steep slopes or low permeability soils. Another mechanism (Dunne) occurs when soil moisture is saturated, known as over-saturation, is more common in flat areas with permeable soils or near wetlands [14]. The river Mixcoac is a typical mountain stream, so the Horton mechanism is employed for obtain the infiltration.

By using a transfer function, the precipitation surpluses are converted into direct runoff, and are added to the base flow to obtain the total runoff hydrograph. This scheme corresponds to lumped parameter hydrologic models, which use spatial averages for physiographic features and precipitation and reproduce the temporal variability of the output basin response [15]. Moreover, the distributed hydrological modeling considers the spatial variability of the physical properties and precipitation dividing the basin into sub-basin or cells. Naturally, the development in remote sensing and geographic information systems has facilitated spatially distributed information management. An advantage of distributed models is that they allow the analysis of different elements that influence the hydrological response and can be modified by human intervention, such as the vegetation and land use, and with appropriate calibration. Distributed models can estimate changes in the hydrological response of the basin to extreme precipitation events, caused by these interventions.

Distributed models obtain the flows in each of the sub-basins simultaneously, which can indicate the state of the system at any point of the drainage network and improve flood risk assessment. Namely in distributed models the spatial variation of the characteristics and processes are explicitly considered, while in aggregate models, spatial variations are averaged or ignored.

Although it is believed that implementing Geographic 
Information Systems (GIS), the problem is solved, this is just a tool to facilitate the determination of watershed hydrologic parameters, but no improvements due to spatial data scarcity and/or temporal components of the hydrological cycle. If the input precipitation data is obtained from a sparse density/spatial distribution rain gauge network, these data cannot characterize adequately the rain fields at the same level of spatial detail as the terrain described by the models. This occurs because the rain gauge network does not necessarily detect the most intense storm so often interpolated data or extrapolated are used, resulting in misrepresentation of observed rain fields. In this sense, modelers have great interest in estimating precipitation from data from remote sensing instruments, such as weather radar, which potentially provide estimated rainfall at the spatial detail required by distributed hydrological models. In this regard, a variety of models such as HEC-HMS, SWAT, CEQUEAU, MIKE-SHE, TOP MODEL, MERCEDEZ, Topkapi, etc., consider the use of such data [16].

It is also important to note that distributed models give good results without an excessive amount of parameters. From the operational point of view, the model must be simple and of fast execution, without losing the physical representation of phenomena. The simplicity and agility of the model operation are key factors for applications in operational forecasting, since otherwise there may be too little time for decision making and taking action to mitigate the effects of flash floods. Models with many parameters are only used in experimental watersheds instrumented for this purpose [17]; for this reason, they are not attractive for distributed modeling in countries like Mexico where measurements are scarce.

\section{Methodology}

\subsection{Data Grid Generation}

In distributed hydrological modeling, the Mixcoac river basin is represented by a set of square cells, where each cell is considered as the basic runoff production unit (Figure 2), with a spatial resolution of $1 \times 1 \mathrm{~km}$. The georeferenced grid containing the basin physiographic

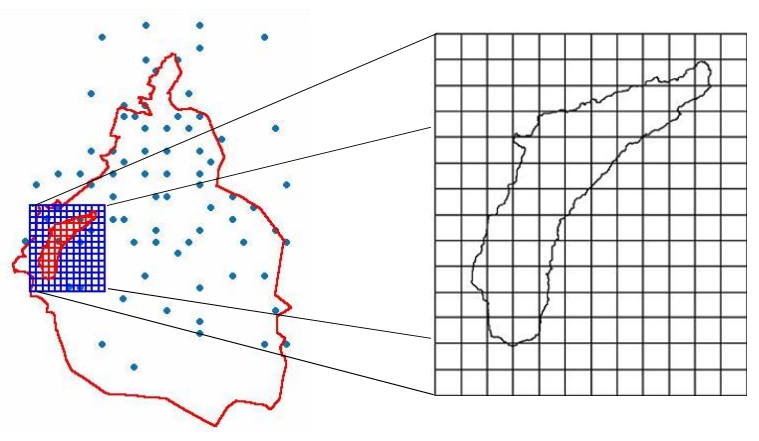

Figure 2. Weather radar grid data area. parameters, such as: the land use, soil type and curve number $(\mathrm{CN})$ obtained from the digital elevation model (DEM). The digital precipitation arrays were estimated from a calibration equation for this radar survey area [18].

Two storms were selected where radar rainfall (every 15 minutes) and runoff data were available. These storms occurred on July 28 and August 231998.

\subsection{Distributed Hydrological Model}

The distributed hydrological model comprises two conceptual sub-models: one for the runoff production in each of the components of the distributed system, and another, which represents travel runoff to be added, from each cell to reach the basin outlet. The following describes each of the sub-models.

\subsection{Runoff Production Sub-Model}

The runoff production in each hydrological unit (cell) is obtained from an infiltration or loss model. These losses consist of initial abstraction and the ground infiltrated water during the storm. Initial losses include water intercepted by the vegetation, the water stored in the depressions of the surface (puddles) and water infiltrated into the ground until it is saturated.

The Natural Resources Soil Conservation Service (SCS), or Curve Number (CN) was used to determine runoff because of its simplicity [19]. This is one of most widely used methods for estimating runoff volumes estimates from a single parameter, the main physical characteristics of the watershed such as slope and use and soil type are considered to produce runoff. This method has the advantage of high predictability and stability; in addition, it is a conceptual method which estimates runoff directly from precipitation [20].

Once the basin has been divided into rectangular cells, the value of the curve number $(\mathrm{CN})$ is set to each of the soil properties (type and land use) and then the direct runoff in each of the cells is estimated. The water volume not converted into runoff is infiltrated into the ground, where part is stored as soil humidity and the rest passes to form deeper underground storage.

The SCS method does not explicitly include any infiltration scheme, so this was estimated directly from accumulated runoff, accumulated precipitation, soil storage capacity and initial losses. The conversion of rainfall to runoff, essential to surface hydrological modeling, is based on the conservation of mass or water balance;

$$
P=P_{e}+I_{a}+F_{a}
$$

where $P=$ total precipitation $(\mathrm{cm}) ; P_{e}=$ effective precipitation; $I_{a}=$ initial infiltration $i(\mathrm{~cm}) ; F_{a}=$ accumulated infiltration $(\mathrm{cm}) . I_{a}$ and $F_{a}$ represent losses and their 
quantification is based on two fundamental assumptions [19]. The first states that the relationship between the effective volume of precipitation $\left(P_{e}\right)$, or direct runoff, and the maximum potential runoff $\left(P-I_{a}\right)$, correspondent to an impervious surface, is equal to the ratio between the real infiltration $F_{a}$ and the maximum potential infiltration $S$ (Equation (2)). The second hypothesis assumes that the initial infiltration is directly proportional to the potential retention (Equation (3)):

$$
\begin{gathered}
\frac{P_{e}}{P-I_{a}}=\frac{F_{a}}{S} \\
I_{a}=\lambda S
\end{gathered}
$$

Emerging Equations (1) and (2):

$$
P_{e}=\frac{\left(P-I_{a}\right)^{2}}{P-I_{a}+S}
$$

From Equation (3), assuming $\lambda=0.2$,

$$
P_{e}=\frac{(P-0.2 S)^{2}}{P+0.8 S}
$$

$S(\mathrm{~cm})$ is given:

$$
S=\frac{(2540-25.4 C N)}{C N}
$$

And $P_{e}(\mathrm{~cm})$ is obtained [21] as follows:

$$
P_{e}=\frac{\left(P-\frac{508}{C N}+5.08\right)^{2}}{P+\frac{2032}{C N}+20.32}
$$

The curve number $(\mathrm{CN})$ is determined from the land use and soil type defined by the US Soil Conservation Service, and the values of $P$ and $P_{e}$ are expressed in $\mathrm{cm}$. Equations (6) and (7) are valid for $P \geq I_{a}$. The parameter $I_{a}$ depends on regional geological and climatic factors.

The main hydrological interest in land use maps lies in the infiltration modeling as a function of soil properties, thereby capturing spatial variability. To determine infiltration parameters from soil properties require some reclassification of representative soil parameters units for the hydrological model. The SCS proposed a criterion for to estimate the effective precipitation in terms of total precipitation and soil characteristics from a table of values for the curve number according to soil type [22]. For the particular case of Mexico, the classification hydrological soil texture and curve number given by [23] were used (Tables 1 and 2). Soil properties (Table 1), depending on their permeability, is used to define the hydrological soil type. Table 2 describes the use of soil, which together with the soil type defined in Table 1, and the slope, enables allocation of the curve numbers. Geo-referenced soils, vegetation and topography maps
Table 1. Hydrological soil type classification (source [23]).

\begin{tabular}{ccc}
\hline $\begin{array}{c}\text { Hydrological } \\
\text { Soil Group }\end{array}$ & Properties & Permeability \\
\hline A & $\begin{array}{c}\text { Sands with little slime and } \\
\text { clay (minimum runoff) }\end{array}$ & Very High \\
B & Fine sands and slime & Good \\
C & $\begin{array}{c}\text { Very fine sands, slime and } \\
\text { quite clay } \\
\text { Clays in large quantities, } \\
\text { shallow soils almost } \\
\text { impermeable } \\
\text { (maximum runoff) }\end{array}$ & Medium \\
D & Low \\
\hline
\end{tabular}

(DEM) facilitate the processing and spatial allocation of curve numbers. Once curve numbers maps were obtained $(\mathrm{CN})$, then Equation (7) is applied to obtain the runoff generated by each storm.

\subsection{Runoff Routing Sub-Model}

The routing of effective precipitation $\left(P_{e}\right)$ at the watershed outlet is an interdependent component in the hydrological cycle, while a proportion of the rainfall is lost to infiltration, excess rain generates runoff, which accumulates and drains through the stream network to the basin outlet. The widely used transfer hydrological method the unit hydrograph [24] - is applied to this experimental watershed.

The basin was divided into cells, which represent a set of elements where the continuity equation is applied. The change in the volume $V_{s}$ stored in the drain network element during a time interval expresses the difference between the stored volume at the end of the previous period and the stored volume in the end of the next period. That is, the change in storage $V_{s}$ is equal to the difference between the volume of water entering $V_{i}$ and leaving the soil volume $V_{o}$ during the time interval $\Delta t$ :

$$
V_{s}=V_{i}-V_{o}\left(\bar{I}_{t}-\bar{O}_{t}\right) \Delta t \bar{O}_{t}
$$

where $\bar{I}_{t}$ and $\bar{O}_{t}$ are the mean input and output flood discharges, respectively, during the time interval $\Delta t$. The previous equation can also be represented as:

$$
V_{s}=\int_{t_{0}}^{t_{1}}(I-O) d t
$$

or in finite differences as:

$$
V_{s}=\left(\frac{I_{t_{0}+} I_{t_{1}}}{2}-\frac{O_{t_{0}+} O_{t_{1}}}{2}\right) \Delta t
$$

The stream flow routing from any point to the basin outlet can be modeled by a simple aggregation through the distributed unit hydrograph or the Clark modified unit hydrograph [25] also called isochrones distributed unit hydrograph [26], (Figure 3). 
Table 2. Soilcover (source [23]).

\begin{tabular}{|c|c|c|c|c|c|}
\hline \multirow{2}{*}{ Cover type } & \multirow{2}{*}{ Slope \% } & \multicolumn{4}{|c|}{ Hydrologic soil group } \\
\hline & & A & B & C & $\mathbf{D}$ \\
\hline No cultiveted & - & 77 & 86 & 91 & 94 \\
\hline \multicolumn{6}{|c|}{ Row crops } \\
\hline Straight row & $>1$ & 72 & 81 & 88 & 91 \\
\hline Straight row & $<1$ & 67 & 78 & 85 & 89 \\
\hline Contoured & $>1$ & 70 & 79 & 84 & 88 \\
\hline Contoured & $<1$ & 65 & 75 & 82 & 86 \\
\hline Terraced & $>1$ & 66 & 74 & 70 & 82 \\
\hline Terraced & $<1$ & 62 & 71 & 78 & 81 \\
\hline \multicolumn{6}{|l|}{ Small grain } \\
\hline Straight row & $>1$ & 65 & 76 & 84 & 88 \\
\hline Straight row & $<1$ & 63 & 75 & 83 & 87 \\
\hline Contoured & $>1$ & 63 & 74 & 82 & 85 \\
\hline Contoured & $<1$ & 61 & 73 & 81 & 84 \\
\hline Terraced & $>1$ & 61 & 72 & 79 & 82 \\
\hline Terraced & $<1$ & 59 & 70 & 78 & 81 \\
\hline \multicolumn{6}{|l|}{ Rotation meadow } \\
\hline Straight row & $>1$ & 66 & 77 & 85 & 89 \\
\hline Straight row & $<1$ & 58 & 72 & 81 & 85 \\
\hline Contoured & $>1$ & 64 & 75 & 83 & 85 \\
\hline Contoured & $<1$ & 55 & 69 & 78 & 83 \\
\hline Terraced & $>1$ & 63 & 73 & 80 & 83 \\
\hline Terraced & $<1$ & 51 & 67 & 76 & 80 \\
\hline \multicolumn{6}{|l|}{ Grassland } \\
\hline- & $>1$ & 68 & 79 & 86 & 89 \\
\hline- & $<1$ & 39 & 61 & 74 & 80 \\
\hline Contoured & $>1$ & 47 & 67 & 81 & 88 \\
\hline Contoured & $<1$ & 6 & 35 & 70 & 79 \\
\hline $\begin{array}{l}\text { Permanent } \\
\text { grassland }\end{array}$ & & 30 & 58 & 71 & 78 \\
\hline \multicolumn{6}{|l|}{ Forest } \\
\hline Very sparse & - & 56 & 75 & 86 & 91 \\
\hline Sparse & - & 46 & 68 & 78 & 84 \\
\hline Normal & - & 36 & 60 & 70 & 77 \\
\hline Dense & - & 26 & 52 & 62 & 69 \\
\hline Very dense & - & 15 & 44 & 54 & 61 \\
\hline \multicolumn{6}{|l|}{ Roads } \\
\hline Dirt & - & 72 & 82 & 87 & 89 \\
\hline Paved & - & 74 & 84 & 90 & 92 \\
\hline Residential area & - & 77 & 85 & 90 & 92 \\
\hline Cemeteries & - & 68 & 79 & 86 & 89 \\
\hline Brush & - & 48 & 67 & 77 & 83 \\
\hline Parks & - & 53 & 72 & 83 & 88 \\
\hline
\end{tabular}

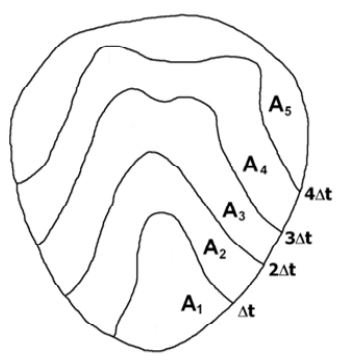

(a)

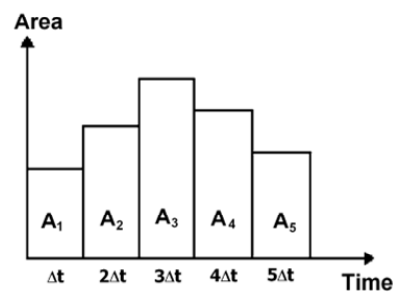

(b)
Figure 3. (a) Isochrones; and (b) Time-area histogram for a watershed (adapted from [27]).

The runoff routing to the basin outlet was performed using the Muskingum method. This method employs the continuity equation (Equation (10)) and a relationship between storage $V$ and inputs and outputs of the analysis section (Equation (11)).

$$
V=K[x I+(I-x) O]
$$

where $I$ is the inflow, $O$ is outflow, $K$ is the attenuation coefficient and $x$ storage weight factor that relates the input and output storages in the current segment.

\subsection{Distributed Unit Hydrograph}

In order to use weather rainfall data, the method of Clark unit hydrograph must be modified to apply in distributed hydrological models and hydrological forecasting [25]. The conceptual model of this approach to distributed models is shown in Figure 4.

This type of unit hydrograph is interpreted as the result of the combination of a pure translation process, followed by a routing in a linear storage. According to this scheme, the actual travel time of a water particle is given by the time-area diagram plus the retaining time in the linear reservoir [17].

This method requires the estimation of four parameters for determining the hydrograph of the basin: the time of concentration $t_{c}$; the Muskingum storage attenuation coefficient $K$; the basic flow recession constant $R$ and a time-area histogram that is used to obtain the initial infiltration $I_{a}$ and infiltration potential maximum $S$. The concentration time $t_{c}$ is defined as the time which the precipitation takes to reach the basin outlet from most remote point. This is a measure of pure delay, regardless of the effect of storage. In the literature there are several equations to calculate the concentration time $t_{c}$ [28], in this study the Kirpich equation was used:

$$
t_{c}=0.000325\left(\frac{L^{0.77}}{S^{0.385}}\right)
$$

with,

$t_{c}$-concentration time (hours),

$L$-river bed length (m), 
$S$-basin average slope (dimensionless).

The storage attenuation coefficient $K$ is the second parameter and is a measure of the delay caused by natural storage. For calibration of this parameter an initial value of $K=0.6 t_{c}$ is assumed [23]. The recession constant $R$ is a measure of the flow rate decrease in the recession curve between $Q_{i}$ and $Q_{i-1}$ interval. That is,

$$
R=Q_{i} / Q_{i-1}
$$

The fourth parameter (the time-area histogram) represents the watershed area contributing to runoff at the basin outlet in a given time and transforms the effective rainfall hyetograph into a runoff hydrograph, regardless of time storage. This area is obtained by constructing a map of isochrones, defined with travel time from each cell to the basin outlet (Equation (12)). By relating the areas between isochrones with corresponding time interval, the time-area histogram of the basin is obtained. This parameter is very important in this methodology because, together with the storage constant $K$, it determines the runoff response of the basin to its outlet (Figure 4).

\section{Hydrological Model Calibration}

Hydrologic model calibration was performed with the storms of July 28 and August 23, 1998 with precipitation mapped every 15 minutes. The study period was from 18:00 to $00: 00 \mathrm{~h}$ (local time) on 28 July and from 16:45 at 18:45 h (local time) on 23 August.

The rain period matrices for storm August 23, 1998 are shown in Figure 5. They show the evolution of the storm approaching the basin until it finally dissipates. This allowed obtaining the rainfall-runoff model to experimental river basin Mixcoac.

The grid parameters represent the cells as sub-basins, in this way, from the current length and slope of each cell the travel time to the basin outlet is estimated to create
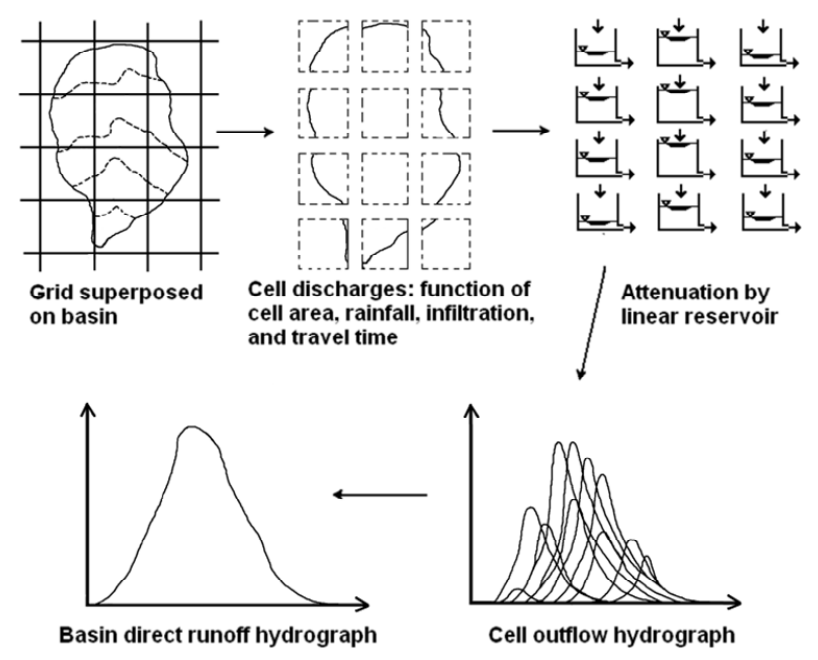

Figure 4. Conceptual model of clark method for distributed parameters (adapted from [25]). the isochrones (Figure 6). The spatial variation of the curve number $(\mathrm{CN})$ was determined using a Geographic Information System (GIS) in raster format, ensuring that the study area and the data format matching the radar rainfall grid. For this grid, land use and soil type maps (Figure 7) of the study area were used. This format allows the $\mathrm{CN}$ of each of the cells in the runoff generation model to be included as input (Figure 8).

Finally using the modified Clark method, this uses the Histogram Time-Area (HTA) defined with subareas built between consecutive isochrones from the remote areas to the basin outlet. This HTA is the basis to transform rainfall into runoff and is determined from the convolution equation. The time interval used in the hydrograph basin response defines the travel time between two adjacent isochrones defined by [27] as:

$$
Q_{j}=\sum_{i=1}^{j} E_{i} A_{j-i+1}
$$

where: $j$ is the number of time intervals, $Q$ is the basin outlet runoff, $E$ is the excess rainfall intensity and $A$ is the area enclosed between isochrones. This method calibrates the model until the hydrograph estimate is comparable to the observed hydrograph of selected storms. The rainfall and runoff data were used as observed data to calibrate the hydrological model.

\section{Results}

With the proposed methodology, the hydrological modeling was performed and the results obtained are shown in the Figures 9 and 10. The parameters obtained for the two storms are shown in Table 3.

Where $I_{a}$ is the initial infiltration, $S$ is the retention potential, $\boldsymbol{t}_{c}$ is the concentration time of the watershed, $K$ is the Muskingum storage coefficient, $\boldsymbol{Q}_{\boldsymbol{b}}$ is the starting base runoff, $R$ is the recession constant and $\boldsymbol{Q}_{\boldsymbol{u}}$ is the threshold base runoff.

Figures $\mathbf{9}$ and $\mathbf{1 0}$ show, for the event on July 28, the difference in volume between the measured and the observed hydrograph is $5 \%$, and for the event of August 23 the difference is $1 \%$, while the peak occurs in the first case with a delay of 30 minutes, and the second with an advance of 30 minutes. These differences in volumes and the time in the peak flow could be associated to the limited information available to calibrate the model.

Table 3 lists the seven parameters required for model

Table 3. Parameters resulting for each storm.

\begin{tabular}{cccccccc}
\hline \multirow{2}{*}{ Date } & \multicolumn{7}{c}{ Basin Model Parameters } \\
\cline { 2 - 8 } & $\boldsymbol{I}_{\boldsymbol{a}}$ & $\boldsymbol{S}$ & $\boldsymbol{t}_{\boldsymbol{c}}$ & $\boldsymbol{K}$ & $\boldsymbol{Q}_{\boldsymbol{b i}}$ & $\boldsymbol{R}$ & $\boldsymbol{Q}_{u}$ \\
\hline July 28 & 0.6 & 0.125 & 0.25 & 1.0 & 0.6 & 0.8 & 0.1 \\
August 23 & 0.6 & 0.41 & 0.25 & 1.0 & 0.6 & 0.8 & 0.1 \\
\hline
\end{tabular}


$16: 45$

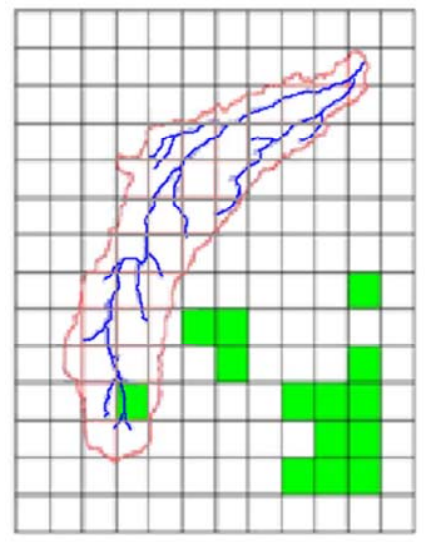

$17: 30$

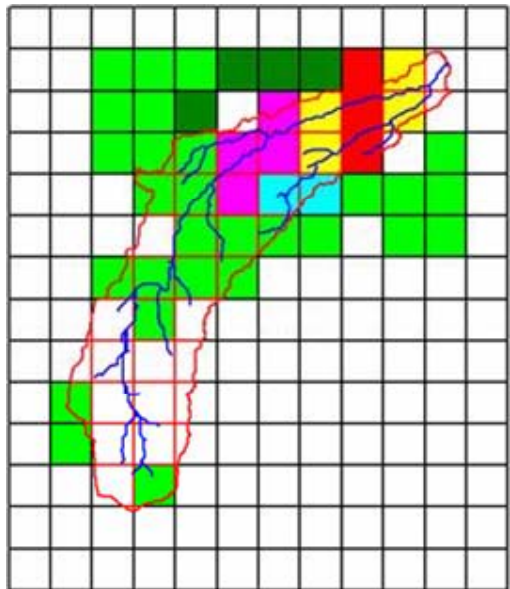

18:15

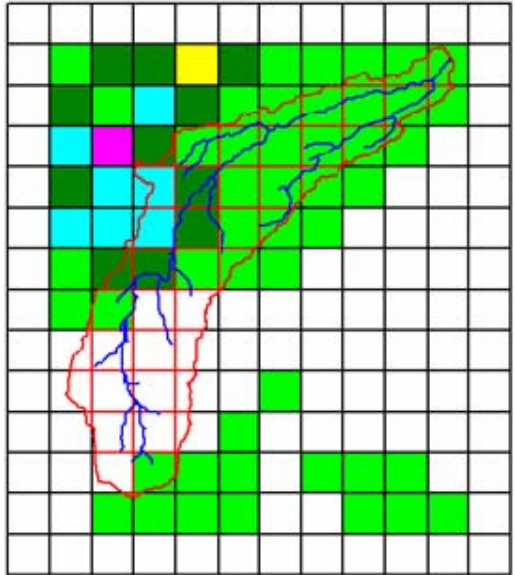

$17: 00$

\section{Mixcoac river \\ Watershed \\ Radar grid}

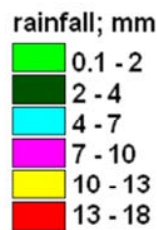

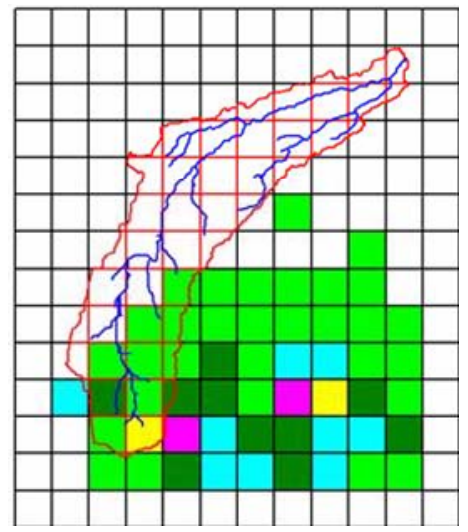

$17: 45$

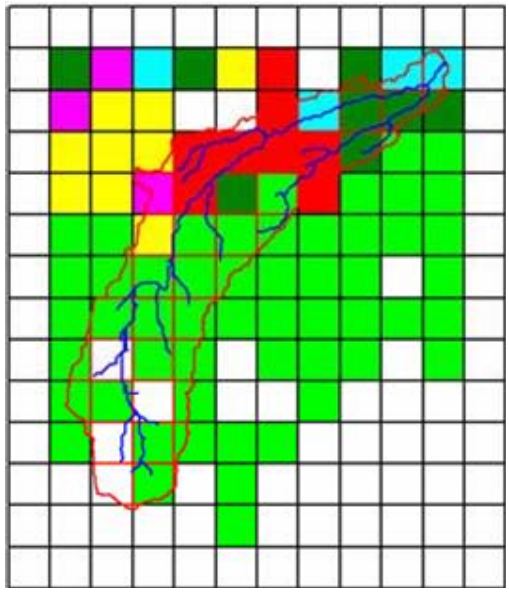

$18: 30$

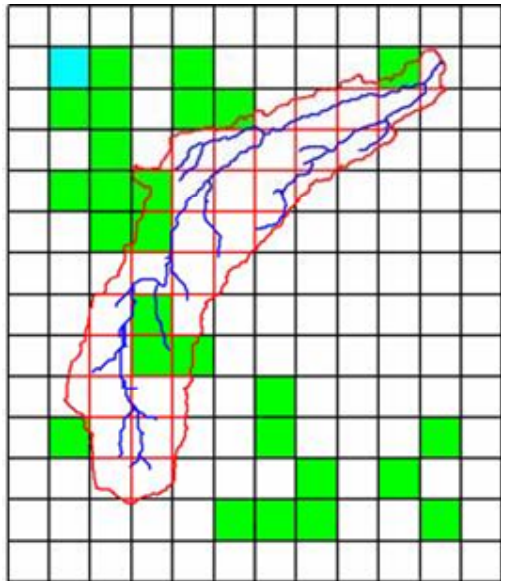

$17: 15$

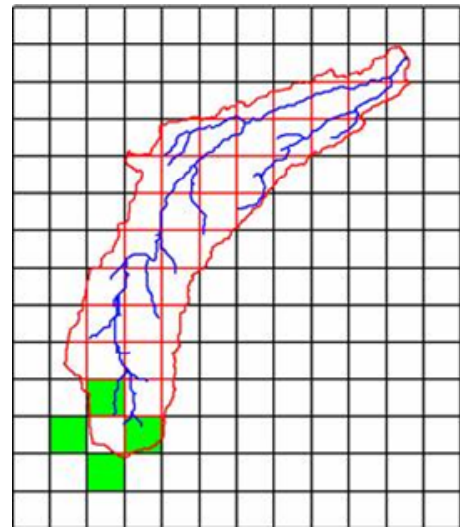

18:00

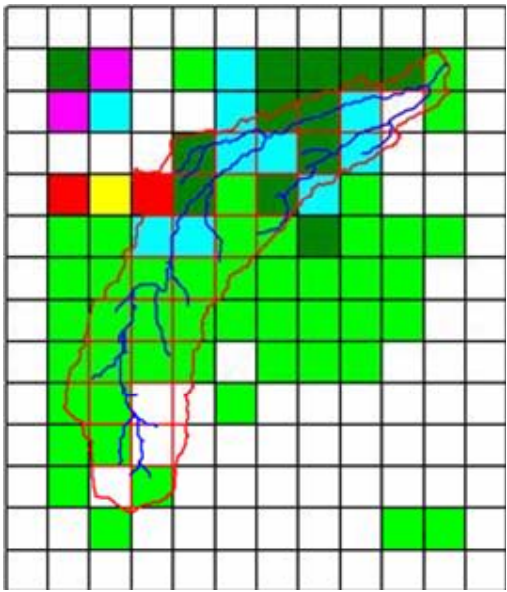

$18: 45$

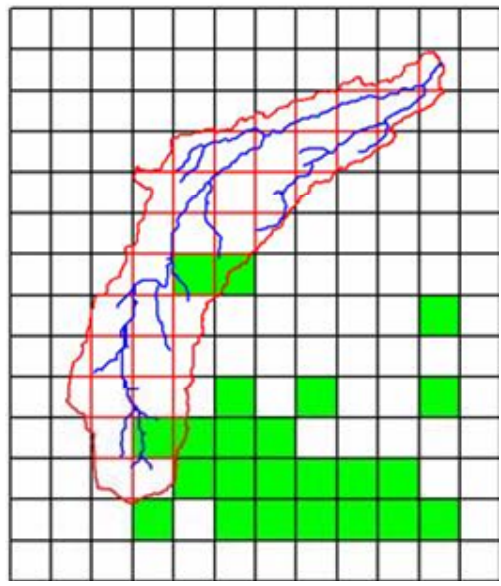

Figure 5. Precipitation matrix every 15 minutes for 23 August 1998 (16:45 - 18:45, local time).

calibration: initial infiltration $\left(I_{a}\right)$, and potential retention $(S)$ are influenced by the antecedent soil moisture. The time of concentration $\left(t_{c}\right)$ and storage coefficient $(K)$ affect the shape of the hydrograph. Meanwhile, initial base runoff $\left(Q_{b i}\right)$, the recession constant $(R)$ and threshold based runoff $\left(Q_{u}\right)$ are affected by the observed historical base flow parameters.

The physical parameters of the basin, which can be considered constant, were obtained with the software HEC-GEOHMS. However, thinking of a future operational hydrological model and with the intent to encourage the use of radars and distributed hydrological models, as an additional product of this study, the software Runoff Forecast Model (RFM) was created, for calculation of variable parameters required by the model's hydrological basin Mixcoac [29]. This software is available com- 


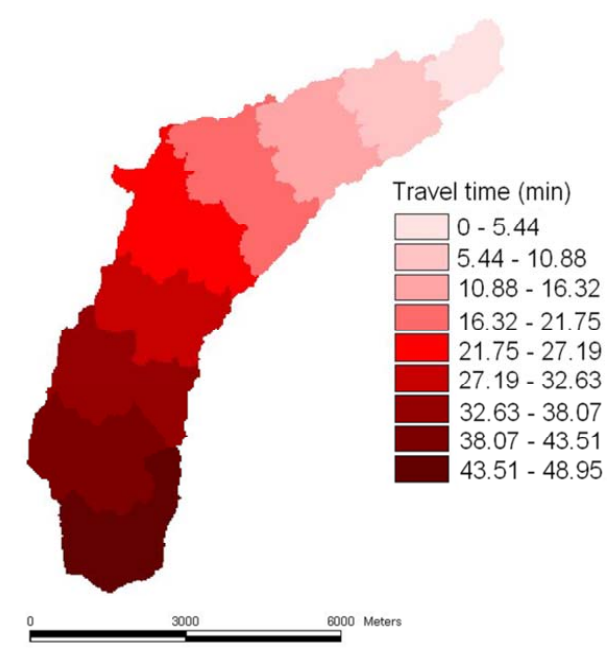

Figure 6. Mixcoac basin isochrones maps.

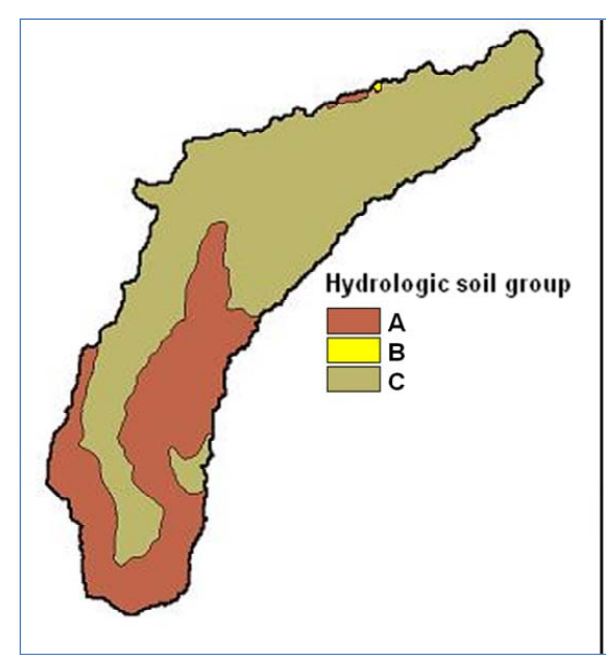

(a)

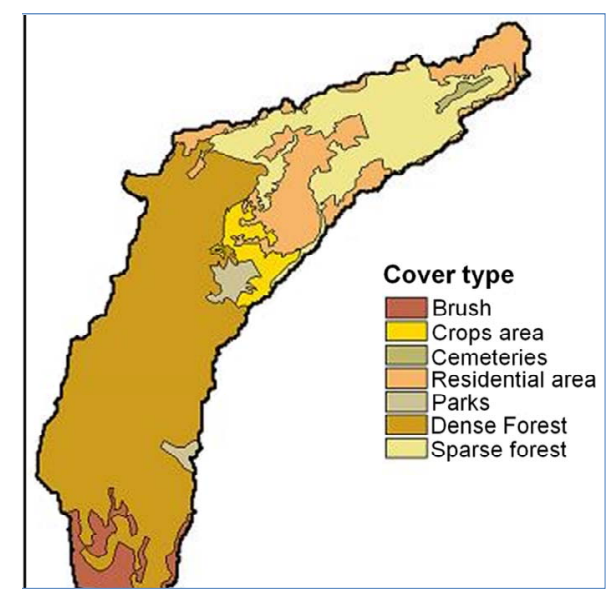

(b)

Figure 7. Map of hydrologic soil type (a) and use land (b).

pletely free of all hydrologists interested in distributed hydrological models. The RFM software, along with its manual (in Spanish) and application example can be

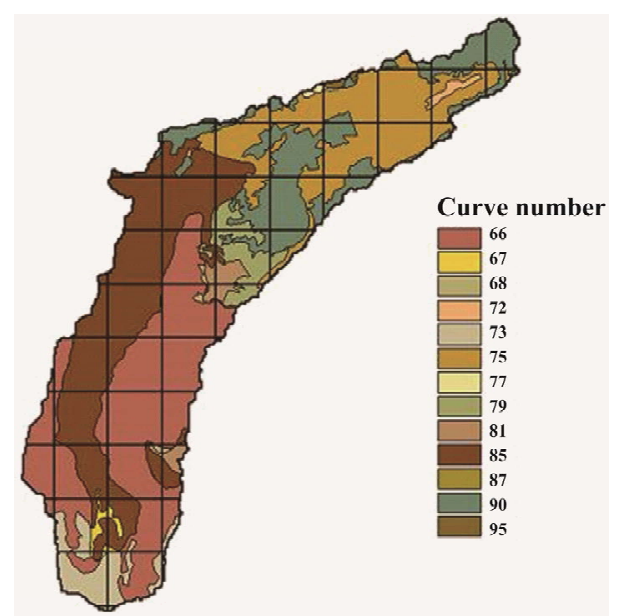

Figure 8. Soils curve number in the Mixcoac Basin.

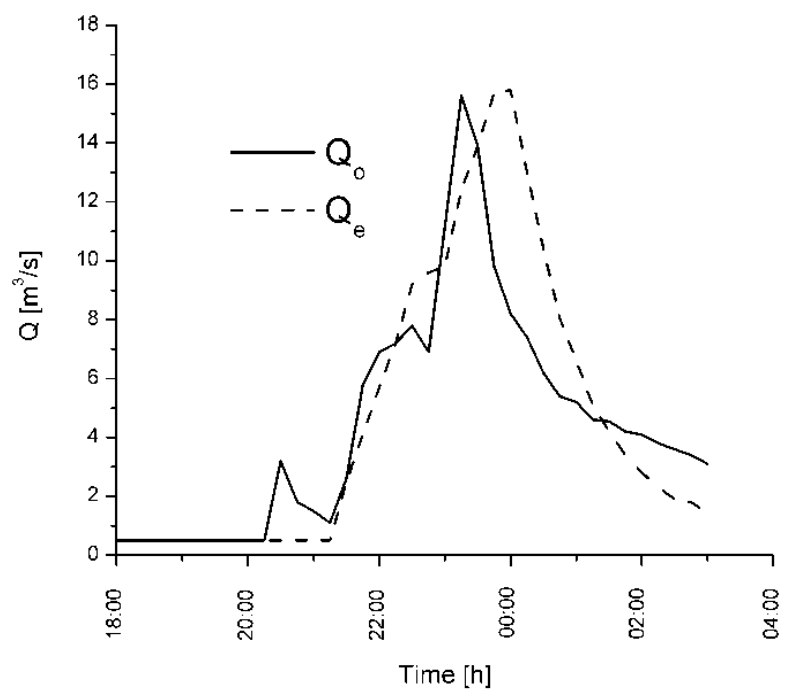

Figure 9. Outflow hydrograph for the storm of July 28, 1998.

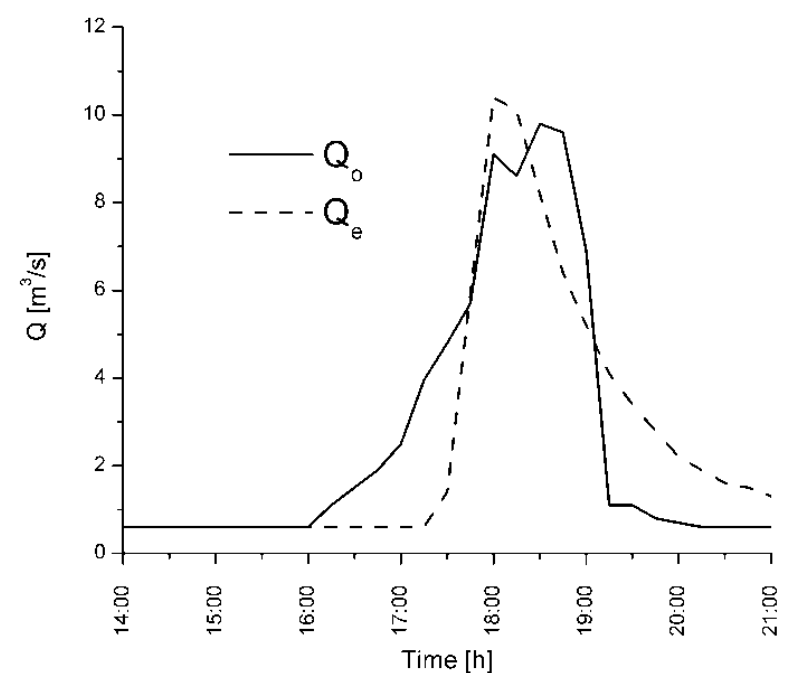

Figure 10. Outflow hydrograph for the storm of August 23, 1998. 
downloaded from the Engineering Institute of the National Autonomous University of Mexico [30].

The results show that radar data input in operational hydrological models can be of great help for flood forecasting in real time and useful to the Meteorological Service of any country. Currently, the weather radar is not seen as the only solution to flood problems, but as part of a whole observation system that includes automatic weather stations, radar, satellite and also regional weather forecast models. The estimation of rainfall from satellite data has been developed extensively in recent years and the proposed Global Precipitation Measurement (GPM) is giving great support to researchers, developers and operational hydrologists. Moreover, mesoscale forecast models, such as WRF provide a great advantage in urban hydrology and other fast response watershed, as the forecast window is important in helping to anticipate sites of high flood risk and issue warning notices for this population. Additionally, radars and satellites can be used to generate immediate forecasts (nowcasting), a very useful product in urban hydrology and mountain river basins. All of these rainfall product can be used as input into the operational hydrological models developed here.

\section{Conclusions}

The major physical significance of distributed models, as used here, is to consider temporal and spatial variability of storms and the spatial variability of soil characteristics of the basin in order to accurately reproduce the hydrological processes inside the watershed, thereby generating more realistic and accurate hydrographs. In this sense, the weather radar is an excellent option to estimate the spatial variability of precipitation affecting hydrological processes within a watershed. In addition, as the response of the basin is non linear, the distributed model allows more basin accurate integration.

Concerning model parameters considered, the initial infiltration and potential retention of soil moisture were calibrated considering runoff volumes shown in observed hydrographs and it was seen that only in the case of the second parameter there is a variation from one storm to another, mainly due to changes in the humidity. In the case of the two selected storms, infiltration parameters showed that, for the storm of July 28, the infiltration is less than in the case of the August 23 storm. This is an indication that the second storm occurs when the soil moisture is greater than the first one.

The difference between measured and estimated volumes are $5 \%$ and $1 \%$ for storms in July and August, respectively, providing an accurate estimation of the peak discharge volume, although its timing is less accurate. However, if a larger number of events are available for calibration, the results can be considerably improved. Moreover, of the seven parameters used in the calibration model, six remain constant and only one is variable - the antecedent moisture. This is a problem not yet solved by hydrologists, since it is difficult to estimate the soil moisture conditions when a rainfall event occurs. Except for this problem, the model is operationally simple and produces valuable information for decision-making in high-risk area. In addition, of the seven parameters required by the model, three of them, relating to base flow, can be obtained directly from the historical analysis, leaving only four for calibration.

This effort also aims to establish the basis for real time storm monitoring systems, in order to integrate them into an early warning system in Mexico river basins with major flooding risks, as part of the non-structural measures which should be implemented to increase resilience in flood prone areas. The investment in this type of measure is far less than the economic losses which occur each year in these areas of the country [31]. The methodology shown can be used in other basins. Additionally, this type of hydrological modeling is also useful to assess the uncertainty in runoff forecasting models in real time.

In an attempt to encourage the use of remote sensing instruments in operational distributed hydrological models, the Runoff Forecast Model (RFM) was developed. This model can be downloaded from the website of the Institute of Engineering of UNAM.

\section{Acknowledgements}

The authors would like thank the National Weather Service of Mexico and the Water System of the City of Mexico, for the data provided and PAPIIT, under contract IT100712, and CONACYT-SEMANART, under contract 107997, for the financial support in the development of the distributed hydrological model using weather radar data.

\section{REFERENCES}

[1] J. Soussan and I. Burton, "Adapt and Thrive: Combining Adaptation to Climate Change, Disaster Mitigation, and Natural Resources Management in a New Approach to the Reduction of Vulnerability and Poverty," UNDP Expert Group Meeting, Integrating Disaster Reduction with Adaptation to Climate Change, Havana, 17-19 June 2002, pp. 28-44.

[2] Undp Expert Group Meeting, "A Climate Risk Management Approach to Disaster Reduction and Adaptation to Climate Change. Integrating Disaster Reduction with Adaptation to Climate Change," Undp Expert Group Meeting, Havana, 17-19 June 2002, 234 p.

[3] UIP and UNISDR, "Disaster Risk Reduction: An Instrument for Achieving the Millennium Development Goals," Advocacy Kit for Parliamentarians, Inter-Parliamentary Union, Geneva, 2010.

[4] K. J. Beven, "Distributed Models," In: M. G. Anderson 
and T. P. Burt, Eds., Hydrological Forecasting, John Wiley \& Sons Ltd., Chichester, 1985, pp. 405-435.

[5] M. Smith, "NOAA Technical Report NWS 45," National Oceanic and Atmospheric Administration, Boulder, 2004, p. 62.

[6] V. P. Singh and D. A. Woolhiser, "Mathematical Modelling of Watershed Hydrology," Journal of Hydrologic Engineering, Vol. 7, No. 4, 2002, pp. 270-292. doi:10.1061/(ASCE)1084-0699(2002)7:4(270)

[7] J. M. Faures, D. C. Goodrich, D. A Woolhiser and S. Sorooshian, "Impact of Small-Scale Rainfall Variability on Runoff Modeling," Journal of Hydrology, Vol. 173, No. 1-4, 1995, pp. 309-326. doi:10.1016/0022-1694(95)02704-S

[8] J. Morin, D. Rosenfeld and E. Amitai, "Radar Rain Field Evaluation and Possible Use of Its High Temporal and Spatial Resolution for Hydrological Purposes," Journal of Hydrology, Vol. 172, No. 1-4, 1995, pp. 275-292. doi:10.1016/0022-1694(95)02700-Y

[9] D. Guichard, R. García, F. Francés and R. Domínguez, "Influencia de la Variabilidad Espacio-Temporal de la Lluvia Mediterránea en la Respuesta Hidrológica en Cuencas Pequeñas y Medianas," XXI Congreso Latinoamericano de Hidráulica, Sao Paulo, 2004.

[10] E. B. Vieux, "Distributed Hydrologic Model Using GIS," Kluwer Academic Publisher, Norwell, Vol. 38, 2001, p. 293.

[11] F. Rivera-Trejo, G. Soto-Cortés and B. Méndez-Antonio, "The 2007 Flood in Tabasco, Mexico: An Integral Analysis of a Devastating Phenomenon," International Journal of River Basin Management, Vol. 8, No. 3-4, 2010, pp. 255-267. doi:10.1080/15715124.2010.508746

[12] V. Magaña, J. Pérez and M. Méndez, "Diagnosis and Prognosis of Extreme Precipitation Events in the Mexico City Basin," Geofisica Internacional, Vol. 41, No. 2, 2003, pp. 247-259.

[13] R. E. Horton, "The Role of Infiltration in the Hydrologic Cycle," Eos Transactions, Vol. 14, No. 1, pp. 446-460.

[14] M. Sivapalan, K. Beven and E. Wood, "On Hydrologic Similarity 2. A Scaled Model of Storm Runoff Production," Water Resources Research, Vol. 23, No. 12, 1987, pp. 2266-2278. doi:10.1029/WR023i012p02266

[15] S. M. Jay, "Comparison of Distributed Versus Lumped Hydrologic Simulation Models Using Stationary and Moving Storm Events Applied to Small Synthetic Rectangular Basins and an Actual Watershed Basin," Ph.D. Dissertation, The University of Texas, Arlington, 2007, p. 419.

[16] B. Lastoria, "Hydrological Processes on the Land Surface: A Survey of Modeling Approaches," Universidad de Trento, Trento, p. 60.

[17] J. Vélez, "Desarrollo de un Modelo Hidrológico Conceptual y Distribuido Orientado a la Simulación de Creci- das," Ph.D. Thesis Dissertation, Universidad Politécnica de Valencia, Valencia, 2001, p. 266.

[18] B. Méndez-Antonio, R. Domínguez, G. Soto-Cortés, F. Rivera-Trejo, V. Magaña and E. Caetano, "Radars, an Alternative in Hydrological Modeling. Lumped Model," Atmósfera, Vol. 24, No. 2, 2011, pp. 157-171.

[19] V. P. Singh and D. K. Frevert, "Mathematical Models of Large Watershed Hydrology," Water Resources Publications, Highlands Ranch, 2002.

[20] V. M. Ponce and R. H. Hawkins, "Runoff Curve Number: Has It Reached Maturity?" Journal of Hydrologic Engineering, Vol. 1, No.1, 1996, pp. 11-19. doi:10.1061/(ASCE)1084-0699(1996)1:1(11)

[21] F. Aparicio, "Fundamentos de Hidrología de Superficie," Editor Limusa, México, 1994, p. 305.

[22] US Army Corps of Engineers, "Hydrologic Modeling System HEC-HMS, User's Manual, V. 2.1," Hydrologic Engineering Center, 2001, p. 178.

[23] R. M. Domínguez and S. J. Gracia, "Manual de Diseño de Obras Civiles, Pérdidas," Comisión Federal de Electricidad, México, 1981, p. 46.

[24] L. K. Sherman, "Stream Flow from Rainfall by the Unit Graph Method," Engineering News-Record, Vol. 108, 1932, pp. 501-505.

[25] D. W. Kull and A. D. Feldman, "Evolution of Clark's Unit Graphs Method to Spatially Distributed Runoff," Journal of Hydrologic Engineering, Vol. 3, No. 1, 1998, pp. 9-19. doi:10.1061/(ASCE)1084-0699(1998)3:1(9)

[26] D. R. Maidment, "Developing a Spatially Distributed Unit Hydrograph by Using GIS," Proceeding of $\mathrm{Hy}$ droGIS'93, IAHS Publication, Wallingford, No. 211, 1993, pp. 181-192.

[27] B. P. Saghafian, P. Julien and H. Rajaie, "Runoff Hydrograph Simulation Based on Time Variable Isochrone Technique," Journal of Hydrology, Vol. 261, No. 1-4, 2002, pp. 193-203. doi:10.1016/S0022-1694(02)00007-0

[28] M. V. Ponce, "Engineering Hydrology: Principles and Practices," Prentice Hall, Upper Saddle River, 1996, p. 640.

[29] R. M. Domínguez, G. E. Garduño, B. Méndez-Antonio, R. Mendoza, J. M. L. Arganis and E. E. Carrizosa, "Manual del Modelo Para Pronóstico de Escurrimiento. Instituto de Ingeniería," Universidad Nacional Autónoma de México, México DF, 2008, p. 101.

[30] http://aplicaciones.iingen.unam.mx/ConsultasSPII/Buscar publicacion.aspx

[31] Cenapred, "Características e Impacto Socioeconómico de los Principales Desastre Ocurridos en la República Mexicana en el Año 2008," Secretaría de Gobernación, Sistema Nacional de Protección Civil y Cenapred, 2008, p. 368. 